\title{
DISCURSO CONSTELAR E CONTINGÊNCIA: A PREGNÂNCIA CONTEMPORÂNEA DE MALLARMÉ
}

\section{CONSTELLATE DISCOURSE AND CONTINGENCY: MALLARMÉ'S CONTEMPORARY PERMANENCE}

\author{
Diana Junkes Martha Toneto ${ }^{1}$ \\ UNESP - Universidade Estadual Paulista (IBILCE)
}

\begin{abstract}
RESUMO: O objetivo deste artigo é discutir o poema "Um lance de dados", de Mallarmé, por meio do estabelecimento de convergências teóricas entre a leitura jakobsoniana, a psicanálise lacaniana e alguns elementos da análise do discurso de linha francesa. O poema, considerado marco da poesia na modernidade, já engendrou inúmeros discursos a seu respeito, o que nos autoriza a considerá-lo aqui como invenção permanente ou, ainda, como um lance de dados em eterno turbilhonar. Atenta aos ruídos desses discursos e disponível à escuta teórica que contribui para a análise crítica do poema, a leitura aqui empreendida aposta nos ganhos que a leitura do poema de Mallarmé tem para a percepção do estado das artes da poesia contemporânea, que dele herdou a dupla face da moeda lírica: a alta revisão das possibilidades de invenção e a excessiva metalinguagem.
\end{abstract}

PALAVRAS-CHAVE: Mallarmé; "Um lance de dados”; contingência; psicanálise; discurso.

\footnotetext{
${ }^{1}$ UNESP/ São José do Rio Preto. Professora de Literatura Brasileira. Vice-líder do Grupo de Estudos de Poesia (GEP/ UNESP SJRP); Pesquisadora do Grupo CASA (UNESP/Araraquara); Pesquisadora do Grupo ADInterfaces (USP- Ribeirão Preto). Publica regularmente em periódicos de seletiva política editorial entre os quais destacam-se: Revista Via Atlântica (USP-SP); Revista Itinerários (UNESP/Ar), Revista Alpha (UNESP), Revista Letras de Hoje (PUC-RS), Revista Todas as Letras (Mackenzie); Revista Signótica (UFG) Revista Texto Poético (GT Texto Poético da ANPOLL). Também possui artigos publicados em livros por editoras de reconhecida competência, tais como Annablume, Laboratório Editorial da Faculdade de Ciências e Letras - UNESP/ Araraquara, Editora Pedro e João, Editora da Universidade Federal do Ceará.
}

Endereço: Rodovia SP- 328, km 310 - Ribeirão Preto/ Bonfim Paulista. Condomínio Gênova, casa 11. Ribeirão Preto - São Paulo/ Brasil. CEP 14110-000/ dtoneto@ibilce.unesp.br.

** Agradeço a generosidade acadêmica dos colegas do Grupo AD-Interfaces, liderado pela Prof ${ }^{\text {a }}$. Leda Tfouni que, em vários momentos, debateram comigo as ideias deste texto entre março de 2009 e junho 2010. Este texto foi apresentado em comunicação oral, em primeira versão bastante resumida, no congresso do ISAPL, em Bari, 2010. 


\begin{abstract}
The aim of this article is to discuss Mallarmé's poem A throw of dice, establishing some theoretical interfaces among Jakobson's reading, Lacan's psychoanalysis and some elements from the French discourse analysis. The poem, considered a milestone of modern poetry, has already engendered various discourses about itself, what allows us to consider it here a permanent invention, or yet, a throw of dice in eternal whirl. Attentive to the roaring of such discourses, and available for listening the theory that contributes to the poem's critical analysis, the reading herein engaged bets on the profit that the Mallarmé's poem study carries, for the perception of contemporary poetry, which inherited from him the double-sided lyrical coin: high revision of the possibilities of invention and very strong metalanguage.
\end{abstract}

KEYWORDS: Mallarmé; A throw of dice; contingence; psychoanalysis; discourse.

A reflexão sobre a contemporaneidade tem ocupado lugar precípuo em papers e em demais trabalhos acadêmicos de todas as áreas, e não é à toa que isso acontece uma vez que é ato inerente ao homem questionar-se sobre si e sobre o mundo que o circunda, bem como sobre os seres, os objetos, as práticas e as manifestações de arte e cultura que o povoam. Pensar o contemporâneo, como sugere Agamben (2009), exige, pois, em primeiro lugar, uma adesão ao tempo e, secundariamente, uma separação, uma defasagem, um descolamento. Essa dupla relação com a temporalidade viabiliza, segundo o filósofo, a percepção das trevas da contemporaneidade, ou seja, a percepção não da luminosidade do nosso tempo, mas daquilo que, entre sombras, aparece-nos como pista para a compreensão de nós mesmos e do mundo em que estamos.

Neste ensaio, o caminho adotado para pensar o contemporâneo da poesia é aquele que aponta para a permanência do moderno no contemporâneo, ou seja, aquilo que aponta para o que ainda é obscuro aos olhos do homem contemporâneo e que o situa em relação ao tempo tanto em termos de defasagem (o moderno antecede o contemporâneo) como em termos de adesão ao tempo (o moderno, anacronicamente, permanece contemporâneo). As relações que são sugeridas aqui aparecem emblematicamente em torno de um nome - Mallarmé - e constelam ao redor de um texto - "Um lance de dados".

\title{
Um lance Odisseia para apresentar o acaso
}

A Odisseia é, para mim, um texto fundador - a experiência e a fragilidade humanas que Odisseu encarna possibilitam sempre vários retornos ao épico de Homero como se, refazendo o percurso do herói, pudéssemos também encontrar uma forma de nomear o nosso desejo: o regresso a "uma possível" Ítaca. O fato é que a literatura, depois de Homero, parece colocar em cheque essa nomeação: será que era mesmo desejo de Ulisses voltar para Ítaca? Até que ponto não se pode duvidar disso, considerando a previsão de Tirésias, apresentada no episódio em que Odisseu desce ao Hades: ao mesmo tempo que garante o regresso do herói a casa, a ambiguidade da previsão indica que sua morte pode vir do mar. É por isso que n' A Comédia, Dante encontra Odisseu, que lhe conta que morreu pelo desejo de aventurar-se no mar: nada, nem o filho, nem a dileta esposa puderam-no prender a Ítaca, e ele, decidido a buscar, talvez, a suma sapiência, movido por intenso desejo de aventura, navega em direção às colunas de Hércules e naufraga: "infin che 'l mar fu sovra noi rechiuso" (INFERNO, XXVI, 142). Em Amorosa visione, Canto XXVII, Bocaccio (1342), com grande sensibilidade, marca a hybris do herói como tentativa de ultrapassar o signo, alcançar o 
desejo, como se pudesse apropriar-se de um perfeito e íntegro objeto a lacaniano. Por tal desmedida, sucumbe o humano herói:

$$
\begin{aligned}
& \text { e quanto volle del mondo sentire, } \\
& \text { ché per voler veder trapassò il segno } \\
& \text { dal qual nessun poté mai in qua reddire, } \\
& \text { io dico forza usando né suo ingegno. }
\end{aligned}
$$

Já no século XX, o poeta Haroldo de Campos retoma esse episódio e escreve Sobre Finismundo: a última viagem (poema de 1990). Nesse poema, é apresentada a última viagem de Odisseu de modo fragmentado e desconcertante, como se o poema fosse feito dos escolhos do navio, experiência abissal de escritura que arrisca o signo ultrapassado: inscrição do desejo no branco da página. Da mesma forma que o herói, o urbano Ulisses de Haroldo naufraga entre açuladas sirenes:

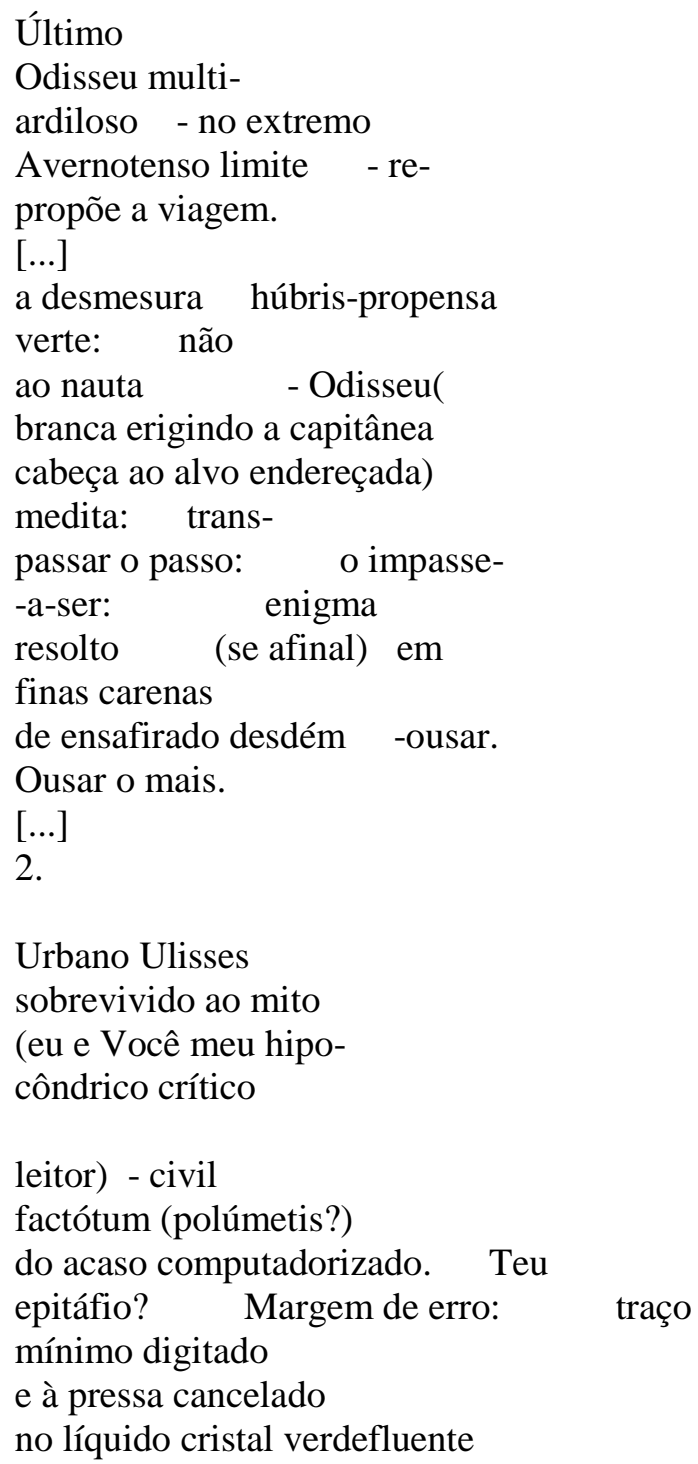

Não há. Vigiam-te os semáforos.

Teu fogo prometéico se resume 


à cabeça de um fósforo
portátil e/ou
ninharia flamífera

\author{
Capitula \\ (cabeça fria) \\ tua húbris. \\ Nem sinal \\ de sereias. \\ Penúltima - é o máximo a que aspira \\ tua penúria de última \\ Tule. Um postal do Éden \\ com isso te contentas. \\ Açuladas sirenes \\ cortam teu coração cotidiano. \\ (CAMPOS, 1998, p. 53).
}

Se o poema é naufrágio, a sua leitura também o é; portanto, sem reconhecer-se escafandrista, o crítico talvez não possa descobrir como o navio-poema torna mais belo o fundo do mar. Paradoxalmente, o fundo do mar torna-se, então, a superfície luminosa, aquela por onde deslizantes significantes desfilam em cadeias e constelações; o mar é, afinal, metáfora invertida do céu. No céu, os significantes constelares exacerbam; de volta à superfície, o escafandrista descobre, então, que aquele fundo luminoso era um espectro, descobre que se preocupou tanto com o fundo, com o "sentido verdadeiro", que deixou de ver a forma, ali, reluzente sobre sua cabeça, ao alcance dos olhos e da imaginação. O crítico não pode, portanto, perder de vista que o naufrágio não está no fundo do mar, mas nos escolhos do navio que, sombriamente, diluem-se na superfície azul da água do mar que a luminosidade do céu deixa ver e articulam sentidos e formas e constelações. Essa breve digressão serve de mote para nosso ingresso no poema mallarmeano, em cuja superfície (materialidade discursiva) proliferam significantes esparsos à espera de atribuição de um sentido que os faça significar, ainda que essa significação não seja outra senão algo da ordem da volatilidade, da efemeridade, da adesão ao tempo e do anacronismo. Além disso, a aventura da linguagem que o poema desvela permite que o vejamos como um "épico da modernidade", sendo o grande herói a própria palavra poética, arma e brasão do poeta que quer usá-la para lutar contra o acaso, que quer ultrapassar o signo. A esse respeito, diz Haroldo de Campos:

De fato, na épica mallarmeana, desubicada (sem lugar) e sem conteúdo diegético propriamente dito, a ação se concentra na "conjunção suprema com a probabilidade", na circunstância de jogo de dados, em que o Humanus (Lê Maitre) enfrenta o Acaso no tabuleiro do Universo. Se o acaso jamais pode ser abolido, poderá - quem sabe? - suspender-se repentinamente, deixando que dele se resgate uma ordem, ainda que fugaz, o desenho de uma constelação (a obra, culminação do ato extremo do Humanus?). [...] o pêndulo [...] não se inclina para o determinismo [...]; oscila, por um momento, no sentido da probabilidade, de uma suspensão provisória que enseja a surpresa de uma ordem, simbolizada na figura constelar do final do poema. Insinua-se no texto mallarmaico uma suspeita de indeterminismo. (CAMPOS, H., 2002, p. 199). 
Para além do que diz Haroldo, penso que o poema mallarmeano é a afirmação do indeterminismo ou, se quisermos, a própria alegoria dele, já que é em torno do verso: "nem um lance de dados/ jamais/ abolirá o acaso" (MALLARMÉ, 1897/2002, paginação irregular) que toda a aventura da linguagem metaforiza a aventura do poeta no mar da linguagem - se não se controla o mar, não se controla a linguagem. Nessa aventura, o homem/poeta, imaginando que controla o seu dizer na totalidade, cai na armadilha dos esquecimentos um e dois (PÊCHEUX, 1988, p. 173), segundo os quais, respectivamente, o sujeito tem a sensação de que é a origem de seu dizer e de que o que diz é igual ao que pensa. Em termos lacanianos, dada a impossibilidade de evitar os atos falhos da linguagem, falamos mais ou menos do que dizemos; falhamos ao dizer (LACAN, 1998, p. 249), porque um lance de dados não abole as impossibilidades do dizer que, como um amálgama, aderem ao possível do dito.

Ou seja: o poeta não tem controle sobre o seu dizer. Ainda que sua consciência da linguagem permita-lhe um "excedente de visão" (BAKHTIN, 1992, p.45) sobre si e sobre o mundo, ele diz mais (ou menos) do que pensa dizer. E Mallarmé trabalha, em seu poema, justamente com essa constatação, fazendo-a em migalhas, pelo corpo de seu texto, que é dilacerado na proporção mesma em que seu autor parece perceber a fragmentação do sujeito, suas falhas e suas faltas também no momento de dizer, de criar o poema. Daí dizermos que o poema mallarmeano alegoriza essa experiência sempre incompleta da linguagem, do simbólico que, nos termos de Safouan (1993), pode ser colocada em termos de "a palavra ou a morte". O poema é a afirmação da vida, portanto, da palavra, ainda que questionando os limites de seu poder de representação, espalhando-se nas páginas, em tipos diversos, tirando proveito dos avanços da imprensa:

\section{UM LANCE DE DADOS}

JAMAIS

MESMO QUANDO LANÇADO EM CIRCUNSTÂNCIAS ETERNAS

DO FUNDO DE UM NAUFRÁGIO

$[\ldots]$

Abolirá

$[\ldots]$

O ACASO

(MALLARMÉ, 2002, paginação irregular)

O poema "Um lance de dados", publicado pela primeira vez em 1897 é, nas palavras de seu autor, "suficiente para abrir os olhos [...] nada ou quase uma arte", feito de subdivisões prismáticas da ideia (MALLARMÉ, 2002, Prefácio ao poema); de uma ideia de palavra poética e de suas possibilidades incontroláveis. Nesse poema, o poeta francês subverte totalmente os padrões da poesia, inova radicalmente a estrutura do texto poético, como diz Augusto de Campos: 
[o poeta] começa a denunciar a falácia e as limitações da linguagem discursiva para anunciar, no Lance de dados, um novo campo de relações e possibilidades do uso da linguagem, para o qual convergem a experiência da música, da pintura, dos modernos meios de comunicação [...] a contestação do verso e da linguagem em Mallarmé, ao mesmo tempo que encerra um capítulo, abre ou entreabre toda uma era para a poesia, acenando com inéditos critérios estruturais e sugerindo a superação do próprio livro como suporte instrumental do poema. (CAMPOS, A., 2002, p.27).

O poema de Mallarmé inaugura um dinamismo no processo de associação de imagens, inserindo, como diz o próprio poeta francês na introdução de seu texto, "subdivisões prismáticas da ideia". A riqueza e a originalidade do poema estão, entre outros aspectos, no emprego de tipos diversos para compor a tipografia, na posição das linhas tipográficas na página, na valorização do espaço branco da página, no uso do léxico, nas rimas, na construção de relações metonímicas entre sons, ritmos, espacialidade, como se o poema fosse uma partitura. Mallarmé leva ao máximo a potencialidade da poesia, ou ainda, da poiésis, isto é, criação:

os jogos vocabulares - paronomásias, assonâncias, aliterações - nas quais a rima tem papel de destaque. As rimas mallarmeanas - rimas equívocas, rimas homófonas, rimas leoninas, que se ecoam, se devoram e se entreespelham contribuem decisivamente para romper, com suas associações verticais, o encadeamento linear do verso. (CAMPOS, 1977, p.29).

Ao romper com a sintaxe, Mallarmé torna-se a consciência extrema do poeta que vive a crise de verso (SISCAR, 2010) e, para além do verso livre, caminha para o verso ideograma em que a junção de duas ideias não é uma terceira apenas, mas acentua as relações estabelecidas entre as duas primeiras, subdividas prismaticamente, como significantes em uma cadeia. Se considerada, então, do ponto de vista gestaltista, essa organização ideogramática em Mallarmé mostra que o todo é mais do que a soma das partes, justamente porque o todo é, além da soma das partes, a relação entre elas. Não se pode deixar de pensar que a poética mallarmeana acompanhava a evolução da técnica e da ciência; é necessário lembrar aqui que o poeta francês é o instaurador do papel do poeta em greve, que se recusa a vender sua força de trabalho poética e a ajoelhar-se diante das imposições da linguagem em uso. O "poeta-grevista" de Mallarmé não vive de sua poesia, e sim de outras fontes de remuneração; a poesia para ele não era meio de trabalho, mas, em termos mallarmarxistas (CAMPOS, H., 2002, p. 27), um fim em si.

Por isso, podemos dizer que a palavra poética mallarmeana encena signos em rotação e também signos em translação, girando em torno de si mesma e de sua matéria significante, ao mesmo tempo em que circunda a estrutura social, justamente porque Mallarmé consolidou as bases para o estabelecimento da função social da poesia como "valor de uso". Segundo Leyla Perrone-Moisés:

Não por acaso Mallarmé comparou a palavra à moeda que passa de mão em mão e se gasta, perdendo o relevo e o brilho. Banalizada e desgastada no manuseio cotidiano, a linguagem perde seu valor-ouro e adquire um mero valor venal. Contaminadas pelas relações econômicas, todas as relações humanas, trocadas no miúdo da fala, se corrompem e se desgastam. A função do poeta moderno, assumida exemplarmente por Mallarmé, é opor-se a esse comércio aviltante, e propor a utopia das trocas linguageiras. Seu trabalho 
consiste em "dar sentido mais puro à palavras da tribo", fazer com que elas, em vez de funcionar apenas como valores de representação da realidade, instaurem uma realidade de valor. (PERRONE-MOISÉS, 2000, p. 32).

De qualquer forma, ainda que a palavra deva superar esses usos comuns, e, na poesia, esse é seu precípuo papel, é importante pensar também na linguagem do poema como instrumento de transformação dessas relações econômicas e sociais. Além de a palavra recuperar seu valor de palavra (valor de uso), é preciso que essa recuperação esteja inserida em um projeto social; é preciso que haja um fortalecimento desta "moeda palavra" como valor de troca mesmo, como instrumento de câmbio entre a obsolescência das potencialidades de um país e sua renovação em todos os sentidos, a começar pela linguagem. Por isso, para além das analogias com as trocas econômicas, há uma profunda reflexão filosófica em Mallarmé e também uma aguda consciência da crise da subjetividade às portas de entrada do século XX, escancarando, como disse anteriormente, a fragmentação do homem e do mundo pela disposição nas palavras na página, que evocam também a disposição de fatos esparsos na memória, como se o ulterior e o originário dialogassem no espaço da página, pela dispersão dos tipos espalhados nos espaços brancos, aparentemente em caráter aleatório, como que sujeitos à deriva e à dispersão, à espera de um mecanismo de autoria que os reúna e faça significar. Neste ponto, é possível perceber que a discussão que é encenada pela performance das palavras no poema de Mallarmé e algo que estava, em seu tempo, além dele é algo contemporâneo por excelência, e basta que se leiam os artigos e se ouçam as palestras e se assistam aos filmes de hoje para que se tenha a dimensão de que Mallarmé talvez estivesse aderido ao seu tempo, mas deslocado para além dele, sendo, portanto, segundo os preceitos de Agamben, contemporâneo de seu próprio tempo e, por isso, talvez permaneça nosso contemporâneo.

O mote do poema, como se sabe, é a deriva de sentidos contra a qual o poeta não consegue lutar. Nesse sentido, o poema, como palco do acaso, pode ser tomado como um sistema fechado onde prevalece a entropia, que nunca decresce e pode ser entendida como "a medida do grau de desordem de um sistema físico" (GLEISER, 2006, p. 387), portanto o poema é o reino do caos. "O preço do novo é o declínio da ordem" (GLEISER, 2006, p. 212), ou seja, a desestabilização causada pela novidade é irreversível. Podemos entender aqui que o novo obriga-nos a um deslocamento de posição discursiva, um giro, outro modo de perceber o entorno e a nós mesmos, como, aliás, ocorre no processo psicanalítico. A arte, depois dos momentos de ruptura gerados, diga-se de passagem, em seu próprio bojo, jamais volta a ser o que era - as mudanças parecem definitivas. Nós também não somos os mesmos depois que aceitamos o risco de olharmo-nos de outro lugar, e, a cada deslocamento, as alterações de ponto de vista, parecem definitivas. Entre o acaso e o determinismo, está o poema, ou ainda, a nossa percepção de nós mesmos e do mundo. Não há espaço para totalizações, pois "o acaso puro é tanto uma negação da "realidade" e de nossa exigência de compreender o mundo, quanto o determinismo o é" (PRIGOGINE, 1996, p. 197). O mundo é, portanto, o mundo das probabilidades e da contingência de um lado; da impossibilidade de apreender o Real na totalidade de outro. Podemos aqui considerar que a probabilidade fica entre o acaso e o determinismo, mediando a ocorrência de ambos.

Como diz Siscar: "Se o lance de dados, em Mallarmé, não chega a abolir o acaso que o tortura, é por ser inequivocamente o problema que ele é também, por assim dizer, a passagem para uma 'solução': a solução segundo a qual não existe solução" (SISCAR, 2006, p. 170). Não se pode lutar contra o acaso, contra a contingência; em relação a ela só é possível uma solução: aceitar que não há solução para evitá-la. O máximo que podemos fazer 
é administrá-la da melhor maneira. Mas, talvez, não seja bem o acaso, entendido no sentido acima, que salte aos olhos no poema; talvez seja um acaso muito mais relacionado não à contingência, mas àquilo que escapa ao dizer do poeta. Pensando especificamente em um lance de dados, em termos probabilísticos, não há acaso, pois certamente uma das faces cairá voltada para cima: a face que emerge é aquilo que se dá a ver. No caso do poema, aquilo que se dá a ver é sintoma. Segundo Tfouni (2008b, p. 148): “o aparecimento de uma deriva possível [na cadeia metonímica do poema, da fala] não deve ser creditado ao acaso, mas antes a algo relacionado com a verdade do sujeito, seu sintoma".

Acrescento aqui que a emergência de determinados significantes no texto encenam o próprio sintoma da crise de representação da poesia na modernidade ${ }^{2}$ e que permanece no discurso da poesia da contemporaneidade. Isso torna o poema um labirinto onde, há mais de um século, leitores se perdem entre um e outro sentido que nenhum fio de Ariadne é capaz de aclarar. De fato, a leitura do poema e sua compreensão em níveis de profundidade diferentes implica a existência de um leitor disposto a se perder e a se encontrar na superfície significante do texto, onde os escolhos do naufrágio, os restos esparsos do desejo encontram-se à espera de atribuição não do sentido, pois ele em si é fugaz, mas de um sentido para aquilo que, entre as ondas, flutua e diz algo de nós para nós mesmos nessa busca homérica de um mais além do sentido, da palavra, ainda que saibamos que nada além dela é possível. Ultrapassar o signo é buscar a ruptura com o simbólico, por isso o poema não pode abolir o acaso; controlá-lo seria tornar o Real, entendido no sentido lacaniano, possível, e bem o sabemos que ele não é. Mas, enquanto palco em que se revelam sintomas, o poema é capaz de administrar o que surge na materialidade discursiva, de modo "aparentemente" casual e, por que não dizer, contemporâneo o suficiente como os roteiros dos filmes e o enredo dos romances e dos contos que mais espelham o esfacelamento da subjetividade, do tempo, do espaço e das fronteiras entre gêneros e nações.

\section{A modernidade, o oximoro poético e a luta contra o acaso}

A concepção de poesia que orienta as formulações que fazemos aqui é jakobsoniana. Roman Jakobson, a partir das formulações de Buhr, apresenta, em 1958, o artigo Linguística e Poética, em que discute seis funções da linguagem. Nesse artigo, Jakobson busca compreender o que determina a mensagem poética. Segundo ele, podemos falar em poesia quando, numa obra literária, aparece poeticidade: uma função poética, centrada na mensagem e de alcance decisivo, permitindo-lhe reger as demais funções da linguagem. O que organiza essa poeticidade dos textos poéticos é o que chamou de dominante. Acreditava que as funções da linguagem (emotiva, conativa, fática, metalinguística, referencial e poética) obedecem a uma hierarquia; em outras palavras, estão tensionadas no discurso, pois ocorrem ao mesmo tempo, embora uma predomine sobre as outras.

\footnotetext{
${ }^{2}$ Usar a linguagem imposta significaria, para o poeta que deseja fazer greve, aceitar que houvesse apropriação de mais-valia sobre seu trabalho. Ao transformar a linguagem em um fim em si, incorporando em seu valor todo o trabalho gasto para produzi-la e nada mais, o poeta rompe com a lógica perversa da acumulação e lança a poesia para um futuro ideal: sem mais-valia, onde só o trabalho socialmente útil será capaz de manter o funcionamento da sociedade. Vale ressaltar que, em termos da teoria marxista, só é socialmente útil aquilo que passa por transformação garantida pelo uso de força de trabalho. Portanto, ao pontuar o trabalho do poeta, os poetas críticos da modernidade de fato cumprem seu papel atribuindo à poesia uma função social.
} 
A ideia de hierarquia das funções da linguagem refuta, portanto, a noção de poesia como desvio da norma, para afirmá-la como parte dos mecanismos de comunicação, que pode se manifestar de acordo com a ênfase à mensagem, inclusive em processos comunicativos que não sejam exclusivamente literários. Dito de outro modo, onde normalmente se vê erro e desvio, Jakobson vê estrutura e criação, seja na fala do afásico, da criança, da poesia (LEMOS, 1997, p. 15).

No caso da poesia, a ênfase na mensagem é especialmente interessante pela especificidade do texto poético em que significante e significado são aproximados. O processo pelo qual se manifesta essa aproximação entre significante e significado é o que a teoria jakobsoniana denomina projeção do princípio da equivalência do eixo paradigmático sobre o eixo sintagmático. Como se sabe, a construção da mensagem é baseada na complexa interação entre operações de seleção (entre uma variedade de sinonímias, antonímias, contrastes, equivalências) e combinação, em que a primeira normalmente precede a segunda. Por isso, a leitura de poesia não pode deixar de considerar os significantes - porque eles estão dispostos no poema com a intenção de provocar um efeito de sentido. Quando se opera a projeção que origina a função poética, as relações de semelhança (metafóricas) e de contiguidade (metonímicas) passam a se confundir ou a coincidir, determinando a emergência de um dominante poético. Como diz Jakobson:

Em poesia, não apenas a sequência fonológica, mas, de igual maneira, qualquer sequência de unidades semânticas, tende a construir a equação. A similaridade superposta à contiguidade comunica à poesia sua radical existência simbólica, multíplice, polissêmica [...]. em poesia, onde a similaridade se superpõe à contiguidade, toda metonímia é ligeiramente metafórica e toda metáfora tem um matiz metonímico. (JAKOBSON, 1999, p. 149-150).

Em poesias barrocas, por exemplo, esse procedimento pode ser observado de modo bastante reiterado. Para Severo Sarduy, os textos barrocos requerem um esforço interpretativo; o desafio da compreensão do que ele chama, em primeira instância, de substituição (metáfora) e, em segunda instância, de proliferação (metonímia):

Outro mecanismo de artificialização do barroco é o que consiste em obliterar o significante de um significado dado, substituindo-o não por outro, por distante que este se encontre do primeiro, mas por uma cadeia de significantes que progride metonimicamente e que termina circunscrevendo o significante ausente, traçando uma órbita ao redor dele, órbita cuja leitura - que chamaríamos leitura radial - podemos inferi-lo. [...] No nível do signo a proliferação poderia ser esquematizada do seguinte modo: (SARDUY, 1979, p. 62). 


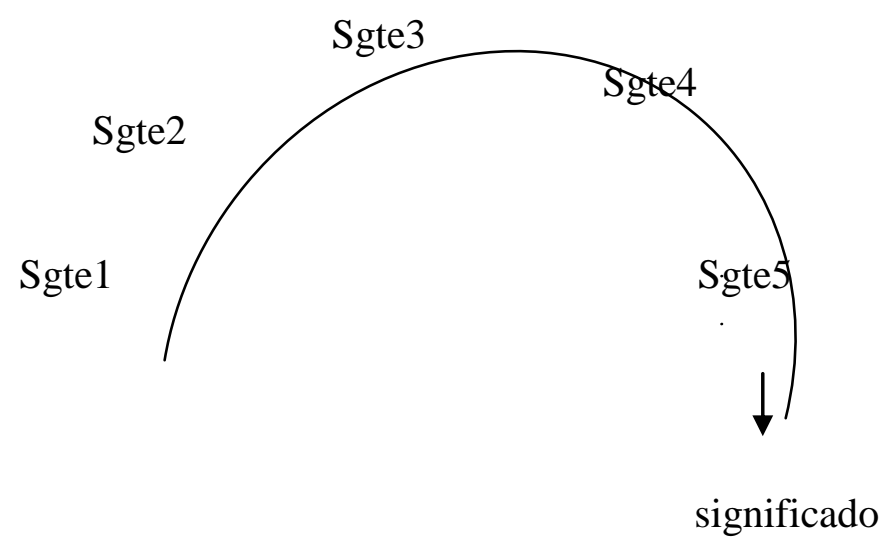

Nesse caso, a aproximação entre significante e significado mencionada sofre um esgarçamento dado, justamente, pela "proliferação" dos significantes que se espalham em cadeia, no discurso. As metáforas continuam metonímicas, porém é cada vez mais difícil especificar a que se referem, dado o deslocamento em cadeia. Essa perspectiva de abordagem remete ao que Lacan chama de cadeia de significantes, em que prevalece uma ordem de representação (que não significa necessariamente uma ordem linear); a cadeia possibilita que os traços que o sujeito toma do Outro o representem e o façam reconhecido por esse Outro. Assim, ainda que, como no diagrama de Sarduy, haja um deslocamento dos significantes que engendrem, pela atuação da função poética, o inesperado, o inusitado e o impensável, porque esse deslocamento se dá em cadeia, ele pode ser lido, com maior ou menor dificuldade, já que sgte1:sgte2:sgte3:sgte4:sgte5. A dificuldade de rastrear essa cadeia não implica sua corrupção, pois há uma ordem de representação, um conjunto de traços, cujo estranhamento causado pode ser compreendido como sintoma, algo que não é atributo do acaso, mas da "verdade" do sujeito:

Revendo, a partir de um ponto de vista psicanalítico, a colocação de Jakobson sobre o advento do inesperado, temos aí todos os fatos discursivos que caracterizam as formações do inconsciente: os lapsos, jogos de palavras, trocadilhos, chistes, etc., que se caracterizam por uma quebra na mensagem supostamente organizada, e pelo advento de uma verdade que não é de modo algum intrínseca ao valor verdade do enunciado, nem ao seu caráter linear de comunicação de um pensamento organizado nos moldes cartesianos. Trata-se aí da verdade do sujeito, que é indiciada pelo seu sintoma (TFOUNI, 2008a, p. 75).

Por mais que o texto em função poética apresente essa luta contra a arbitrariedade e que chegue bem perto de derrubá-la, ele é feito de palavras, e, entre as palavras e as coisas, há um hiato, uma dispersão, ou ainda, a própria deriva, a qual também significa. Como diz Leda Tfouni:

Em suma, a deriva é constituída pela palavra que falta, tão importante quanto a que é enunciada, atestando a presença da alteridade. Essa outra voz que de repente se faz ouvir ao lado das palavras do sujeito: eis a deriva instalada. Nesse processo ocorrem esquecimentos, lapsos, hesitações, falsos começos. 
A deriva refere-se ao fato de que não há ajuste perfeito entre as palavras e as coisas que elas designam [...].Tanto a dispersão quanto a deriva quebram a aparente unidade do sujeito, e indiciam a irrupção da alteridade, ou do não UM. Imaginariamente, equivalem a uma visão do corpo esburacado, sem unidade, perfurado pelo real (TFOUNI, 2008a, p.76).

Nos poemas modernos e contemporâneos, herdeiros de Mallarmé, isso se acentua como reflexão a partir do momento que o poeta, cônscio de uma necessidade de ruptura das estruturas analógicas mais simples, passa a estabelecer metáforas cuja referencialidade apresenta-se ampliada e, por isso, instaura novas possibilidades de leitura, marcadas pela iconização, ou seja, quanto mais as palavras tornam-se ícones, mais as relações analógicas se estabelecem também por contiguidade e não apenas por semelhança, por isso as metáforas são também metonímias que fundam uma realidade outra, a poética. A metonimização é crucial para esses poemas porque, de um lado, mostra a crítica da metáfora em termos de procedimento poético, uma falência desta decretada pelo próprio poeta que quer desreferencializar o texto, esgarçando-o; de outro lado, importa a metonimização para mostrar que essa desreferencialização de todo é impossível, pois o procedimento metonímico tem sempre em si algo que se perde, algo que se mantém metafórica e silenciosamente em ação no discurso. Assim, a metonímia marca a falta e o silêncio que podem ser apreensíveis pelos espaços em branco que significam latentemente, como ocorre em "Um lance de dados".

Mais uma vez é possível pensar aqui na situação contemporânea, não apenas na situação da literatura e das artes, mas em nossa posição diante de um mundo feito de esgarçamentos e de silêncios, de ocos de sentido e de profusão de tipos e de informações. De um lado, aceitamos a desautomatização da linguagem como algo indiscutível; de outro, não conseguimos deixar de pensar no peso sobre os nossos ombros que tal desautomatização, que tal desejo de invenção e renovação permanentes nos impõem.

A liberação da linguagem dos seus automatismos proposta pelos poetas desde o final do século XIX e, notadamente, no início do século XX significou o mesmo que as ideias de Copérnico para seu tempo: havia uma poesia antropocêntrica, ptolomaica, cujo foco era o eu lírico; e há a poesia pós-Mallarmé que reforça o estatuto primeiro da mensagem, o sol (centro do sistema) da poesia: funda-se uma poesia "palavracêntrica" e, ao mesmo tempo, pela valorização dos espaços em branco, "silenciocêntrica", já que o silêncio é constitutivo do poema. Não se tratava apenas de usar palavras, mas de transformar as palavras e o processo de escrever no plano temático da poesia engendrado pela percepção do poeta. Isso trouxe então um problema para a poética da modernidade. A função poética, por ser resultado do princípio de projeção, opera ambiguidades; a reflexão do poeta sobre a linguagem, por sua vez, resulta em metalinguagem e, portanto, na existência de uma função metalinguística que explicaria essas "ambiguidades". Ocorre que a metalinguagem do poema moderno é cifradíssima a tal ponto que é mais fácil acessar o sentido do texto pela leitura da poeticidade, já assumida como algo típico do poema, do que pela metalinguagem.

Ora, a metalinguagem serviria para explicar, enquanto a poeticidade, para obliterar; diante da prevalência de ambas, nesta poesia de qual se fala aqui, temos um oximoro poético: o que explica oblitera; o que oblitera facilita a entrada do leitor no texto ${ }^{3}$. Esse paradoxo traz implicações para a forma pela qual a questão da luta contra o acaso surge nos

\footnotetext{
3 Procuro aprofundar essa discussão a partir das colocações feitas por Haroldo de Campos no texto "Comunicação na Poesia de Vanguarda", publicado em "A Arte no horizonte do Provável” (1977).
} 
poemas da modernidade e, mais particularmente, no poema de Mallarmé, em que essa luta é enunciada e assumida como risco da criação poética.

A metalinguagem, no lugar de elucidar, de explicar, torna ainda mais hermética a mensagem poética, como se, por meio dela, viessem à tona os sintomas, agora sim, do poeta, os quais são impossíveis de apreender, já que a "escuta" a que o poema dá acesso, nesse sentido, é vaga. Não será a necessidade de metalinguagem do poema moderno uma necessidade do poeta? Nesse ponto, é preciso marcar as restrições dessa metalinguagem. Para Arrivé (1994, p.113-130), há uma diferença entre o que os linguistas chamam de metalinguagem e o que Lacan trata por metalinguagem. No caso da metalinguagem dos linguistas, é preciso dizer que é quase uma tautologia, pois: "toda linguagem é metalinguagem de seu registro próprio" (ibid, id). Para a psicanálise, segundo a visada de Arrivé, a metalinguagem é inexistente porque Lacan, nesse caso, parece referir-se a algo que pudesse ser metalinguagem da lalangue, e é em relação a ela que não há metalinguagem:

Lacan nunca distingue claramente a linguagem-objeto da qual é dito que não há metalinguagem. [...] Aqui uma resposta vem aos lábios: não será essa linguagem-objeto a linguagem com a qual é estruturado o inconsciente? E essa linguagem, por sua vez, será outra senão lalangue? [...] Tudo aqui parece aclarar-se: é de lalangue que não há metalinguagem (ARRIVÉ, 1994, p. 130).

De meu ponto de vista, essa conclusão de Arrivé ajuda a compreender porque é que, na poesia moderna (e na contemporânea), não é a função poética a maior responsável pela ambiguidade e ciframento do discurso, mas, a metalinguagem: o que escapa à nossa compreensão é a "metalinguagem" do inconsciente do poeta, seu arquivo, sua memória discursiva que podemos, pelo estudo de sua obra, tatear; portanto não é de metalinguagem que se fala, mas de uma manifestação da lalíngua. Ou seja, a mensagem cifrada que do poema emerge - os escolhos do naufrágio que vêm à superfície não são outros restos senão os rastros de uma escrita que o inconsciente do poeta ditou que lemos. Natural, portanto, que atribuamos os sentidos segundo a nossa leitura; jamais segundo o que o poeta poderá ter "querido" dizer. Por isso o poeta é um "fingidor" e por isso lemos no poema as nossas dores, não as dele. Buscamos nossa Ítaca no poema; mesmo incertos sobre ela, é um fim, uma finalidade da leitura que procuramos. Como Ulisses, temos que aprender que o Fado e o fim da jornada importam menos que a travessia - de um lado, queremos a compreensão, o significado do poema; de outro, entendemos que a compreensão está na própria busca, na travessia, na viagem (BARBOSA, 1979, p. 11) a que o périplo do poema dá acesso.

Na Odisseia de Mallarmé, as vozes épicas são ecos do narcisismo do poeta que se olha em seu poema espelho procurando apreender sua imagem refratada na superfície do texto. Vozes que, como a da pobre ninfa Eco, são repetição - será possível fazer o novo? Ou, para retomar uma ideia exposta anteriormente, são recordação e sintoma de um sujeito que vê as trevas de seu tempo (AGAMBEN, 2009). Há, ainda, outra consideração a fazer: essa lalangue que surge no tex to encontra, a despeito de todo o ciframento, um meio de apreensão - nada totalizante, mas um mecanismo que dá acesso à história de leitura dos poetas e do cânone. Em certa medida, ao tentar explicar a sua própria linguagem, o poeta fá-lo do lugar do Outro. Ao identificarmos, no texto, marcas desse "Outro" (AUTHIER-REVUZ, 2004), como encontramos, por exemplo, marcas de Homero em Dante, em Bocaccio, em Haroldo de Campos, aproximamo-nos da leitura do sintoma do poeta, no que concerne à sua relação com o cânone, que não deixa de ser uma relação de filiação, de influência, ora afirmada explicitamente, como no poema de Haroldo citado no início do texto, em que vemos várias marcas do "cânone": Homero, Dante, Bocaccio, Baudelaire (crítico leitor), Mallarmé; ora 
negada veementemente, embora pulsante pelos significantes do texto. Por isso, uma crítica como Sandra Nitirni (1997) diz que a pior maneira de sofrer uma influência é negá-la acrescentaríamos denegá-la - e à sua carga "edípica".

A "lalangue" que lemos é aquela cuja apreensão pela cadeia significante conseguimos ter acesso - daí que a leitura do poema moderno, palimpsesto imenso e avassalador, exige do leitor também uma história da leitura que possa ajudá-lo a desvelar a história da leitura do poeta. Ainda assim, sublinhamos parcialmente. Naturalmente, essa algaravia torna obliterado o discurso poético, forçando o leitor a perscrutar, nas malhas do texto, em seus silêncios e versos uma arqueografia da escrita que escreve o sujeito poético, que se inscreve nele, como insígnia, como marca, como estilo a partir do que Lacan denomina constelação de insígnias. Segundo Marcia Rosa:

Tratadas pela psicanálise como significantes imaginários, as insígnias designam as marcas distintivas de um sujeito, os seus emblemas, os seus brasões. [...] com a expressão "constelação de insígnias", Lacan indica que esses significantes emblemáticos introduzem um modo de identificação diferente daquele que é o agrupamento dos traços em cadeia significante. [...] Portanto, ao apresentar o Ideal do Eu como uma constelação de insígnias, Lacan deixa indicado que os traços que o sujeito toma emprestados ao Outro [...] podem também se soltar do sistema significante, serem extraídos da cadeia significante, e se transformarem em insígnias que existem tout seul, absolutamente sós [...]. Redutores do Outro, esses significantes soltos (desencadeados, portanto!) operam fora do sistema simbólico na sua face representativa e comunicativa, fundada na lógica simbólica. Neste sentido, eles operam como letra [...] e neste movimento, a própria hegemonia do simbólico, fundada no binarismo significante, um dos fundamentos do estruturalismo, é colocada em questão. O império do significante transformase em um império de semblantes e ele traz de volta os signos que, ao ressurgirem, portam em seu bojo a contingência do múltiplo (ROSA, 2009, p. $4)$.

A leitura do poema de Mallarmé evoca semblantes e insígnias - soltando-se da cadeia, até pela disposição na página, os significantes se multiplicam e admitem muitas leituras. A meu ver, um dos meios de enfrentar a contingência do múltiplo é tomá-la, em parte, como sintoma. Nada podemos diante das contingências, a não ser agir, falar, enunciar, viver, portanto. Ao falar, escapam, não por acaso, como tentei mostrar, os sintomas. Segundo a psicanálise lacaniana, porque o sintoma está escrito ele pode ser lido, todavia, se não houver ninguém para lê-lo, permanecerá como o silêncio das estrelas e dos espaços infinitos. A leitura do poema-sintoma depende, então, mais da leitura da leitura que o leitor faz de si, do que daquela que ele poderia fazer sobre o poeta. Em outras palavras: a história de leitura do leitor pode encontrar marcas que signifiquem para o leitor e não necessariamente para o poeta, pois há outra história da leitura e outro inconsciente em jogo aí - o do leitor -, e talvez só este século pós-Freud possa nos dar a dimensão do que isso significa. Conforme afirma Paraizo sobre a leitura da literatura:

Não se trata apenas de um efeito retroativo, mas de um reconhecimento posterior de algo que, a partir desse momento, será colocado em posição de anterioridade e de conclusão. A própria lógica do tempo será subvertida. Resta assinalar que a causa é sempre perdida, e que estar perdida é a condição mesma para que ela possa emergir como causa. O tempo, como um operador, 
tal qual ocorre na música, determina a fluência da escrita, não só no que diz respeito à duração da leitura, mas também no que concerne ao tempo evocado nas imagens do texto. $O$ leitor não apenas vai desvendando os precursores que o autor de fato leu, como também aqueles que este sequer conhecia. Dito de outra maneira, o autor cria seus precursores, não porque efetivamente os eleja, de maneira explícita ou não, mas porque o texto sempre faz parte de um tecido maior, tão grande quanto a linguagem e o tempo que ela pressupõe e que estofa, do qual fazem parte infinitos outros autores, que podem vir antes ou depois, sem necessariamente obedecer uma ordem (PARAIZO, 1999, p.22, grifo nosso).

A criação do poema não é uma cena original. Ela advém de uma história do homem e da poesia, o que equivale dizer que o poeta é um leitor do mundo e do cânone e mobiliza, em sua leitura, alguns aspectos que depois serão convertidos em sua própria criação (BARBOSA, 1986), por isso é que se pode dizer, em termos borgianos, que cada escritor cria os seus precursores (BORGES, 1982). Essa questão é extremamente importante, pois marca a influência que pesa sobre o processo criativo e a necessidade que tem o poeta de administrar ativamente uma herança, os espectros que persistem nos arquitextos do cânone. Enfim, a historicidade do poema também é uma história da leitura do poeta. Do ponto de vista da análise do discurso francesa, esse processo torna-se, em parte, acessível a nós porque todo dizer inscreve-se no repetível histórico: o sentido que não se historiciza é ininteligível. $\mathrm{O}$ poema é, pois, uma manifestação ativa da memória discursiva do poeta e do leitor.

\section{A função poética e a história; a metalinguagem e a luta contra o acaso}

A administração ativa dessa memória funciona mais ou menos da mesma forma que o canto do aedo épico. A palavra épica deriva o vocábulo grego epós, que significa voz; o aedo é aquele que costura epéa, vozes, e elabora um canto em que narra os feitos passados. Para fazê-lo, invoca a Musa, e é em relação a esse ponto que a aproximação com a poesia cabe bem. É claro que todo poeta é uma espécie de aedo e que costura vozes e as mistura a seu canto; mas, quando convoca a Musa, não está convocando apenas a memória, mas a memória com poder criativo. A Musa é filha de Zeus e de Mnemosyne, portanto, é fruto da ação do poder sobre a memória (BRANDÃO, 1990, p12); ela tanto é poder, quanto é memória e, mais do que isso, é algo além do poder e da memória, porque é, ela mesma, novidade. A sua presença no canto do aedo garante que o fato acontecido se realize porque enunciado, porque cantado, porque elaborado pelo canto. A Musa é uma espécie de força que visa à contenção da deriva e da dispersão dos sentidos, uma vez que a fala do aedo, sem a sua ajuda, estaria sujeita à deriva, e a autoria seria impossível. Ela é, pois, a força que retroage no texto amarrando sentidos, assegurando a inventividade do texto - a autoria - e, mais do que isso, garantindo que o aedo se diga no discurso (é o que comprova o relato de Ulisses a Alcínoo em A Odisseia).

Um dos modos pelos quais essa historicidade se manifesta no poema é pela atuação da função poética, entendida, então, como força criativa, fruto da ação do trabalho do poeta sobre a memória discursiva e a memória que ele aciona para escrever, daí a sua ambiguidade residir não apenas no princípio de equivalência como postulara Jakobson, mas avançando um pouco, na (im)possibilidade de recuperação de todas as vozes que articulam esse princípio de projeção e que, muitas vezes, escapam ao controle do poeta. Nesse sentido, podemos dizer que, em termos da função poética, o poeta aceita o acaso; aceita os já ditos, mas entende que há aspectos desses já ditos irrecuperáveis inclusive para si, portanto, não 
ditos e até, por que não dizer, interditos que encontram um meio de se manifestar quer pelo silêncio, quer pela obliteração do sentido.

A leitura crítica do poema deve levar em conta, então, a operacionalidade da função poética e, mais do que em outros textos, deve aceitar o estranhamento, a inquietação para que se possa romper com a naturalização dos sentidos, esses também operadores de uma ruptura, porque, nos termos de Mallarmé, dão "novos sentidos às palavras da tribo" (Prefácio ao poema). Esse gesto de leitura, entretanto, pressupõe uma escuta que capte a presença do não dito no que é dito; que capte, entre os silêncios dos versos, um sentido que não é aparente, mas que significa. Isso, todavia, não leva necessariamente a uma análise do texto esclarecedora, como se espera normalmente, mas a um processo em que o leitor-crítico recifra, em seu discurso, o texto; para explicar, metaforiza, cria novos enigmas. Não decifra o texto, recifra aquilo que do texto está também dentro dele, como memória discursiva que vem à tona pela elaboração do processo de análise do poema. $\mathrm{O}$ que define o poema é o olhar do leitor sobre ele, um olhar que se constitui fora dele; mas, ao mesmo tempo, o poema olha para o leitor, há um olhar fora do leitor no poema a defini-lo, a vasculhar as suas gavetas e as suas verdades, os seus afetos e as dissimulações, seus medos e seus anseios, suas paixões e seus desejos. Por isso, Octavio Paz (1982) diz que não é à toa que encontremos no poema o que procurávamos: já estava dentro de nós.

O poeta deixa de ser, a partir desse momento histórico (que, a meu ver, se prolonga, ainda que com variações e contrapontos, entre acordes e dissonâncias, em termos de poesia, de Mallarmé a nossos dias), aquele que vaticina, mas aquele que, assolado por uma crise da individualidade e da linguagem busca a reflexão e a crítica; essas são sintomas e síndromes culturais que marcam o conflito entre a linguagem da poesia, solitária e a busca de uma voz social pelo poeta, de modo que cada elemento do plano da expressão (verso, imagem, ritmo) recupera uma qualidade histórica que marca uma leitura do passado pelo poeta e o quanto essa leitura tem potencial para abrir-se, ao futuro, como diálogo. Como diz João Alexandre Barbosa:

Sintoma de uma leitura incessante da tradição, a alta tensão corrosiva faz com
que certos poetas desprezem a história, mas, mal esse gesto se afirma, o peso
da consciência é restaurado: a qualidade histórica do poema, a sua inevitável
leitura palimpsesta, instila o sabor amargo da dúvida sobre a originalidade.
[... Sendo assim, a historicidade do poema não é um dado que possa ser
relacionado apenas nas relações entre o poeta e as circunstâncias
espaciotemporais - o tempo, no poema, é marcado pelo grau de
intertextualidade. (BARBOSA, 1986, p. 15).

Essa angústia acerca da originalidade, marcada pelo alto grau de intertextualidade do poema moderno, cuja veiculação no poema é, em parte controlada pelo poeta e em parte fruto do acaso, daquilo que seu inconsciente mobiliza e escapa de seu controle, marcam de profunda subjetividade a lírica moderna, mas que por não se querer lírica, ou seja, por pautar-se pela reflexão sobre a linguagem como uma das formas do afastamento do eu sobre o poema, sob o disfarce da ironia, cravam de objetividade a linguagem poética, de modo que é a linguagem da "objetividade" que possibilita a maior densidade subjetiva, daí a exacerbação da metonímia e a contestação da metáfora: para um poeta em crise, a condensação é pouco viável, é instrumento restrito; enquanto o deslocamento dá-lhe ampla margem de manobra. Sendo assim, o poema moderno é aquele que rompe com os padrões analógicos, abrindo espaço para a iconização, para a representação da coisa em si, de modo que a crítica da metáfora se torna uma grande metáfora crítica das 
próprias condições de realização do poema. Aqui retomo uma ideia lançada no início deste artigo: o poema é uma alegoria da própria linguagem em crise:

[...] o poema [...] é, então, aquele que faz da linguagem do poema a linguagem da poesia, interioriza a alegoria ao problematizar os fundamentos alegóricos da linguagem e [...] aponta para as impossibilidades das respostas unívocas para a relação entre o poeta e a realidade. [...] O poema moderno institui-se no horizonte de (in) significação porque busca o significado mais radical de nomear as circunstâncias, daí a radicalidade de colocar em xeque a analogia que é um dos modos de estabelecimento de vínculos entre o poeta e a realidade. Ao pôr em xeque a metáfora, o poema moderno assenta as bases para a crítica da realidade, das formas poéticas, do mundo (BARBOSA, 1986, p. 30).

$\mathrm{Na}$ poesia que vem da modernidade mallarmeana, com a reflexão do poeta sobre a linguagem, há, como já vimos, uma tentativa de ordenação de caos, uma tentativa de controle do acaso, daquilo que escapa ao dizer, uma preocupação consciente com as possibilidades de criação da linguagem e de seus limites. A reflexão sobre a linguagem corrompe, em certa medida, o esclarecimento esperado para instaurar um encantamento outro, dado pelo prazer do corpo a corpo com a cosa mentale que orienta a criação do poeta e também engendra outro estatuto enigmático para o texto: como uma faca de dois gumes, acentua ainda mais a obscuridade, pois o que esclarece não é a linguagem do poema, mas traz à tona, em um gesto oriundo do inconsciente, as próprias insígnias do poeta. Se a função poética opera na cadeia significante, a "metalinguagem" opera na constelação, ela não pode ser tomada isoladamente, mas no conjunto do poema, como discurso a ser analisado. O reino apolíneo da reflexão sobre a linguagem é corrompido pela força dionisíaca do inconsciente que, em atos falhos, traze à tona o que é para o poeta subjetividade profunda, a letra, da qual também não somos, como leitores, capazes de nos aproximar.

De fato, o que ocorre em Mallarmé e também na poesia herdeira de Mallarmé é uma tentativa de deixar a iniciativa às palavras, já que há um esforço do poeta para desaparecer elocucionalmente, justamente como se fosse um processo de livre associação que traz implicações para o desaparecimento forçado do sujeito. A diferença, entretanto, é que, ao contrário da livre associação, o poeta forja esse afastamento. Do ponto de vista da teoria da literatura isso tem implicações importantes, pois se chega a falar em antilirismo. Alerto aqui para uma armadilha: não é a ausência do eu lírico que marca o poema, mas o esforço do poeta em obliterar a presença do lírico para favorecer uma prevalência da função antilírica. Sobre esse aspecto, vale citar um poema de João Cabral ("Dúvidas apócrifas para Mariane Moore"), lido pela crítica, de um modo geral, como o antilírico:

Sempre evitei falar de mim,

Falar-me. Quis falar das coisas.

Mas, na seleção dessas coisas

Não haverá um falar de mim?

Não haverá nesse pudor

De falar-me uma confissão,

Uma indireta confissão,

Pelo avesso e sempre impudor?

A coisa de que se fala 
Até onde está pura ou impura?

Ou sempre se impõe, mesmo impura-

Mente, a quem dela quer falar?

Como saber, se há tanta coisa

De que falar ou não falar?

E se o evitá-la, o não falar,

É forma de falar da coisa?

(MELO NETO, 1997, p. 4)

A linguagem dos poemas da modernidade e da contemporaneidade, e o de Mallarmé é o precursor disso, estabelece um desequilíbrio entre os nomes e as coisas; afirmase pela negação das possibilidades usuais de uso da linguagem; é uma poesia do não e da recusa não como forma de apatia, para afirmá-lo como forma de experiência do não; o nada e o vazio como espaço significante em que aquela crítica do paraíso, chamada linguagem, passa a ser a crítica da linguagem, chamada poesia. A poesia potencializa o fato de a escrita ser um traço no qual se lê um efeito de linguagem que é um efeito de sujeito, do sujeito poético e do sujeito leitor que também emerge por entre os significantes do poema à medida que aceita o risco que é a leitura poética.

O poema que encena esse oximoro poético abarca duas perspectivas de abordagem: uma intransitiva e fechada em si mesma, calcada na reflexão poética, que engendra a composição poética. A outra perspectiva de abordagem é transitiva, voltada para a comunicação poética, é aberta, pois incorpora segmentos da realidade (pensada aqui, como propõem Zizek/ Daly (2006) enquanto imaginário e simbólico), aclarando-os e os intensificando, em especial pelo uso da alegoria que recupera a distância entre o poeta e o leitor, imposta pelo alto grau de complexidade da escrita. A alegoria, segundo Benjamim (drama barroco) introjeta-se na concepção de lírica, e torna passível de interpretação, ou se quisermos, viabiliza a escuta por meio de um gesto de leitura que fisga, no texto, os jogos intertextuais e reconcilia a história circunstancial (do poeta e do leitor) e a historicidade do poema, marcada pela consciência crítica do poeta, cujo acesso é dificultado pela própria escrita do poema. Vê-se aqui que o poema moderno deseja a leitura e a afasta ao mesmo tempo, alegoriza e aprofunda a obscuridade, beirando o indecidível e o inominável; o poema moderno é, assim, uma suspensão da ação, como diria Mallarmé: "um talvez suspenso em céu noturno", reino da constelação e da contingência.

\section{(...) Uma constelação}

não tanto

fria de olvido e dessuetude

$$
\begin{aligned}
& \text { que não enumere } \\
& \text { sobre alguma superfície vacante e superior } \\
& \text { o choque sucessivo }
\end{aligned}
$$

de um cálculo total em formação

vigiando

$$
\text { duvidando }
$$

$$
\text { rolando }
$$

antes de se deter

brilhando e meditando

em algum ponto que o sagre 
Todo pensamento emite um Lance de Dados

(MALLARMÉ, 2002, paginação irregular)

Mallarmé é um desses poetas cujo sintoma ainda está por ser lido; um desses poemas que, como forma de pensamento, paira no ar como um lance de dados. Embora seja clássico e, como tal, prolifere inúmeros discursos a partir de si, o poema mallarmeano guarda um silêncio (talvez um silenciamento) em torno de sua lalangue que ainda está por ser avaliado na contemporaneidade e que muito pode ter a revelar sobre ela. Quem sabe as convergências teóricas aqui brevemente levantadas não possam, em alguma medida, beneficiar-se dessa noite de céu estrelado que é o lance permanente de dados do poema de Mallarmé para retornarem de suas constelações com mais instrumentos para ler o oximoro do poema e para ler, mesmo que contingencialmente, os sintomas do homem contemporâneo que o poema-sintoma desvela.

\section{REFERÊNCIAS}

ALIGHIERI, D. A divina comédia. Trad. Ítalo Eugenio Mauro. São Paulo: Ed. 34, 2004. ARRIVÉ, M. Linguística e psicanálise. Tradução: Mario Laranjeira/ Alain Mouzat. São Paulo: EDUSP, 1994.

AUTHIER-REVUZ, J. Entre a transparência e a opacidade: um estudo enunciativo do sentido. Tradução: Leci Borges Barbisan e Valdir do Nascimento Flores. Porto Alegre: EDIPUCRS, 2004.

BAKHTIN, M. Estética da Criação Verbal. São Paulo: Martins Fontes, 1992.

BARBOSA, J.A. -Um cosmonauta do significante: navegar é preciso. In: Signantia: Quase Coelum Signância: Quase Céu. São Paulo: Ed. Perspectiva, 1979.

. As Ilusões da Modernidade. São Paulo: Perspectiva, 1986.

BOCACCIO. Amorosa Visione Disponível em:

〈http://www.classicitaliani.it/boccaccio/poesia/amorosa_visione.htm>. Acesso em: 16 set. 2010.

BORGES, J.L. Kafka y sus Precursores. In: Prosa completa. Buenos Aires: Bruguera, 1982, vol.2, p. 278-281.

BRANDÃO, J. L. Do épos à epopeia: gênese dos poemas homéricos. Belo Horizonte: Sociedade Brasileira de Estudos Clássicos, nov. 1990, n.12.

CAMPOS, A. Mallarmagem. In: Mallarmé. São Paulo: Perspectiva, 2002.

CAMPOS, H. Caos e ordem: acaso e constelação. In: Mallarmé. São Paulo: Perspectiva, 2002. 1990.

Sobre Finismundo: a última viagem. Ouro Preto: tipografia do fundo de Ouro Preto,

A arte no horizonte do provável. São Paulo: Perspectiva, 1977.

GLEISER, M. A dança do universo. São Paulo: Companhia de Bolso, 2006.

HOMERO Odisseia. Trad. Donaldo Schuler. Porto Alegre: LP\&M, 2007. 
CASA, Vol.9 n.2, dezembro de 2011

Odisseia. Fragmentos. Trad. CAMPOS, H. São Paulo: Olavobrás, 2006.

JAKOBSON, R. Línguística e poética. In: Linguística e comunicação. Tradução: Izidoro Blikstein e José Paulo Paes. São Paulo, Cultrix, 1999, p.118 - 162.

LACAN, J. Escritos. Tradução: Inês Oseki-Dupré. São Paulo: Perspectiva, 1998.

LEMOS, C. A Poética e o significante. In: Revista Traço. Campinas: Escola Lacaniana de Psicanálise, 1997, n.2.

MALlarmé, S. Poesias. Poesias e Estudos Críticos. Ed. Bilíngue. Trad. Augusto de Campos; Haroldo de Campos; Decio Pignatari. São Paulo: Perspectiva, 2002. Suplemento Especial Um Lance de Dados. 1953.

Propos sur la poésie. MONDOR, H. (org.). França/ Mônaco: Éditions du Rocher,

MELO NETO, J.C. O artista inconfessável. São Paulo: Alfaguara, 2007.

MILNER, J-C. A obra clara: Lacan, a ciência, a filosofia. Rio de Janeiro: Jorge Zahar Editor, 1996.

NITRINI, S. Literatura Comparada. São Paulo: Edusp, 1997.

ORLANDI, E. As formas do silêncio. Campinas: Ed. UNICAMP, 2007.

PARAIZO, M.A. O labirinto e a bússola: aspectos do tempo em Borges. São Paulo:

Fundação Memorial América Latina, 2003.

PAZ, O. O Arco e a lira. Rio de Janeiro: Nova Fronteira, 1982.

PÊCHEUX, M. O Discurso: estrutura ou acontecimento. Trad. Eni P. Orlandi. Campinas: Pontes, 2006, $4^{\text {a }}$ edição.

Semântica e discurso. Trad. Eni P. Orlandi. Campinas: Ed. UNICAMP, 1988.

PERRONE-MOISÉS, L. Inútil Poesia. São Paulo: Companhia das Letras, 2004

PRIGOGINE, I. O fim das certezas. São Paulo: Unesp, 1996.

ROSA, M. Da cadeia significante à cosntelação de letras: os signos do gozo. Ágora. Rio de Janeiro: vol. 12, n. 1, 2009.

SAFOUAN, M. A palavra ou a morte: como é possível uma sociedade humana. Campinas: Papirus, 1993.

SARDUY, S. Escrito sobre um corpo. São Paulo: Ed. Perspectiva, 1979.

SISCAR, M. Estrelas Extremas: sobre a poesia de Haroldo de Campos. In: FERNANDES, M.L.O, et. al. Estrelas Extremas: ensaios sobre poesia e poetas. Araraquara: Laboratório Editorial da FCL, 2006.

TFOUNI, L. V. Autoria e contenção da deriva. In: Múltiplas faces da autoria. Ijuí, Ed. UNIJUÍ, 2008, p.141-152.

Mensagem e poesia. A atualidade de Saussure e Jakobson, ou sobre a verdade do sujeito (e do sentido) em deriva. In: GASPAR, N.R.; ROMÃO, L.M.S. Discurso e texto: multiplicidade de sentidos nas ciências da informação. São Carlos, EDUFSCAR, 2008a. 
CASA, Vol.9 n.2, dezembro de 2011

ZIZEK, S.; DALY, G. Arriscar o impossível: conversas com Zizek. Tradução Vera Ribeiro. São Paulo: Martins Fontes, 2006.

Recebido em: 10.06 .11

Aprovado em: 13.10.11 